\title{
Investigation of the Effect of Natural Extract on Corrosion Behavior of Tin in $\mathrm{Na}_{2} \mathrm{CO}_{3}$ Solution
}

\author{
E. Azzouyahar ${ }^{1}, 2$, L. Bazzi ${ }^{1}$, M. Essahli², M. Belkhaouda ${ }^{1}$, L. Bammou ${ }^{1}$, A. Lamiri²
}

${ }^{1}$ Laboratoire Matériaux et Environnement, Faculté des Sciences d'Agadir.

${ }^{2}$ Laboratoire de Chimie Physique Appliquée et Environnement, Faculté des Sciences et Techniques de Settat.

Corresponding author: I.bazzi@uiz.ac.ma

\section{ABSTRACT}

The inhibition effect of eugenol oil (EO) on the corrosion of tin in $0.1 \mathrm{M} \mathrm{Na}_{2} \mathrm{CO}_{3}$ has been studied by electrochemical impedance spectroscopy (EIS) and potentiodynamic polarization technics. The effect of temperature on the corrosion behavior of tin in $0.1 \mathrm{M} \mathrm{Na}_{2} \mathrm{CO}_{3}$ with and without addition of eugenol oil was studied in the temperature range 278-308 $\mathrm{K}$. This compound inhibits the corrosion of tin at low concentration. At $4 \mathrm{~g} / \mathrm{L}$ eugenol oil the inhibition efficiency calculated by potentiodynamic polarization and EIS techniques is $70 \%$ and $82 \%$, respectively. The inhibition efficiency increased with increase of the inhibitor concentration and decreased with increase of medium temperature. Electrochemical impedance spectroscopy was used to investigate the mechanism of corrosion inhibition. Polarization curves reveal that EO acts as a mixed-type inhibitor in corrosive solution. The results obtained from the different corrosion evaluation techniques are in good agreement.

\section{Indexing terms/Keywords}

Electrochemical Impedance Spectroscopy; Potentiodynamic Polarization; corrosion inhibition; tin; Eugenol Oil; $0.1 \mathrm{M}$ $\mathrm{Na} 2 \mathrm{CO} 3$.

\section{Council for Innovative Research}

Peer Review Research Publishing System

\section{Journal: Journal of Advances in Chemistry}

Vol. 5, No. 3

editor@cirworld.com

www.cirworld.com, member.cirworld.com 


\section{INTRODUCTION}

The interest on the corrosion and inhibition behavoiur of tin is due to its important technological application. The corrosion behavior of this metal in aqueous medium has been the subject of several investigators [1-5]. The use of pure tin is greatly restricted by its high fusibility, high price, low hardness, corrosion resistance, wettability and ease of forming alloys[6]. As a result, tin's functionality is typically found in the form of a thin coating or as an alloy with other metal[7]. Because of its utility, the reserch of tin corrosion and its inhibition has become verry impotant.

Recently the research has been focused on the use of the natural products of plant origin contain different organic compounds, and most are known to have inhibitive action [8-14]. Other authors have also shown that the inhibitive effect of some plants solution extract is due to the adsorption of molecules of phytochemicals present in the plant on the surface of the metal, which blocks the metal surface and thus doesn't permit the corrosion process to take place.The encouraging results obtained by this research permit us to test more plant materials extacts.

The electrochemical studies of tin are closely related to its wide applications in industry. Very little work has been carried out in carbonate solutions [15-18], it's reported that'is in bicarbonnate media, potentiodynamic polarization is characterized by formation a layer of passivitation without a break down of passivity and the appearance of two anodic peaks assigned to the formation of Sn(II) an d Sn(IV) species[17,19-20] .

The present work was devoted to study the corrosion inhibition of tin in bicarbonnate sodium solution using a series of green inhibitors by electrochemical impedance spectroscopy and potentiodynamic techniques. The influence of the concentration and temperature was also investigated.

\section{EXPERIMENTAL PART}

\section{2-1 Materiel}

The working electrode was pure tin in a cylindrical shape with an exposed surface area of $0.5 \mathrm{~cm}^{2}$. The samples was mechanically ground successively with 300, 800, and 1200 grit emery paper, degreased in acetone and rinsed with bidistilled water before immersed in the test solution. The corrosive solutions were freshly prepared from analytical grade chemical reagents using doubly distilled water.

We investigated the efficiency of eugenol, thymol and the carvacrol oil as corrosion inhibitors in $0.1 \mathrm{M} \mathrm{Na}_{2} \mathrm{CO}_{3}$ media. These oils are supplied by company called Fluka.

\section{2-3 Polarization measurements}

Electrochemical polarization measurements were carried out in a conventional three electrode cylindrical glass cell platinum electrode was used as a counter electrode and a saturated calomel electrode (SCE) as the reference electrode. The potentiodynamic polarisation curves were recorded using a potentiostat PGZ 301 . The working electrode was initially kept at the free potential for 30 min before recording the cathodic curves up to the $-1200 \mathrm{mV}$ vs. SCE at a scan rate of 1 $\mathrm{mV} / \mathrm{s}$. The inhibition efficiency $E_{p}(\%)$ was calculated using the following equation:

$$
E_{p}(\%)=\left(1-\frac{I_{c o r}}{I_{c o r}^{\circ}}\right) \cdot 100
$$

where $I_{\text {cor }}$ and $I_{\text {cor }}^{\circ}$ are the corrosion current densities of tin in the presence and absence of inhibitor, respectively.

\section{2-4 Electrochemical impedance spectroscopy measurements}

Electrochemical impedance spectroscopy was carried out with a same equipment was used as for the potentiodynamic polarization measurements. The measuring ranged from $100 \mathrm{kHz}$ down to $10 \mathrm{mHz}$ with $10 \mathrm{mV}$ peak to peak amplitude using sinusoidal potential perturbation at the open circuit potential.

The impedance diagrams were plotted in the Nyquist representation. The inhibition efficiency $E_{E I S}(\%)$ was calculated using the following equation:

$$
E_{E I S}(\%)=\left(1-\frac{R_{t}}{R_{t}^{0}}\right) .100
$$

Where $R_{t}$ and $R_{t}^{0}$ are referred to as the charge transfer resistance of tin without and with the addition of the inhibitor, respectively. Double layer capacitance $C_{d l}$ values were obtained at maximum frequency $\left(f_{\max }\right.$ ), at which the imaginary component of the Nyquist plot is maximum, and calculated using the following equation.

$$
\mathrm{C}_{\mathrm{dl}}=\frac{1}{2 \pi \cdot \mathrm{R}_{\mathrm{t}} \cdot \mathrm{f}_{\max }}
$$




\section{RESULTS AND DISCUSSION}

\section{3-1 Electrochemical study of tin in $0,1 \mathrm{M} \mathrm{Na} \mathrm{CO}_{3}$ solution}

Potentiodynamic polarization plots for tin specimen in $0.1 \mathrm{M} \mathrm{Na}_{2} \mathrm{CO}_{3}$ solution at $298 \mathrm{~K}$ is shown in Fig. 1. The curves were swept between -1200 and $1200 \mathrm{mV} / \mathrm{SCE}$ at scan rate of $1 \mathrm{mV} . \mathrm{s}^{-1}$. The active dissolution region involves two anodic peaks (I and II) prior to permanent passive region. These results are similar to those reported by Refaey for tin electrode in carbonate solutions [10,20] and for tinplate by our laboratory [21] .

The first anodic peak located at about $-0.65 \mathrm{~V} / \mathrm{SCE}$ is due to the formation of $\mathrm{Sn}(\mathrm{OH})_{2}$ or $\mathrm{SnO}$ according to the following reaction:

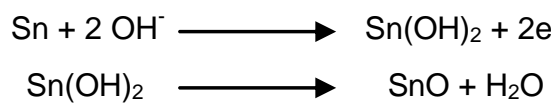

The second anodic peak located about - $0.55 \mathrm{~V} / \mathrm{SCE}$ corresponds to the formation of $\mathrm{Sn}(\mathrm{OH})_{4}$ or $\mathrm{SnO}_{2}$ according to the following reaction:

$$
\begin{gathered}
\mathrm{SnO}+\mathrm{H}_{2} \mathrm{O}+2 \mathrm{OH}-\longrightarrow \mathrm{Sn}(\mathrm{OH})_{4}+2 \mathrm{e}- \\
\mathrm{Sn}(\mathrm{OH})_{4} \longrightarrow \mathrm{SnO}_{2}+2 \mathrm{H}_{2} \mathrm{O}
\end{gathered}
$$

The same explanation is introduced by several authors [2,21-23]. Dehydration of the thermodynamically unstable $\mathrm{Sn}(\mathrm{OH})_{4}$ leads to the stable $\mathrm{SnO}_{2}[24]$. When thesurface is covered with passive film, the anodic current density falls to the lowest value $\mathrm{I}_{\text {pass }}$ indicating a permanent passivation.

The third peak (III) obseved about 0.64 V/SCE beyond the passivity plateau, it cannot be assigned to any particular anodic oxidation reaction [5]. Several authorsattributed the observation of the transpassive region in alkaline media to a solid phase transformation[5,10-12]. It is generally believed that oxygen evolution occurs most probably on a film of metastannic acid $\left(\mathrm{H}_{2} \mathrm{SnO}_{3}\right)[12]$.

For more raised anodic potentials, the field of transpassivity is reached due to the oxidation of solvent according to the reaction:

$$
4 \mathrm{OH}^{-} \longrightarrow 2 \mathrm{H}_{2} \mathrm{O}+\mathrm{O}_{2}+4 \mathrm{e}^{-}
$$

The effect of the addition of eugenol, thymol and carnavol oil at $2 \mathrm{~g} / \mathrm{L}$ on potentiodynamic polarization curvesfor tin in $0.1 \mathrm{M} \mathrm{Na}_{2} \mathrm{CO}_{3}, \mathrm{pH}=10.9$ is shown in Fig. 2 .

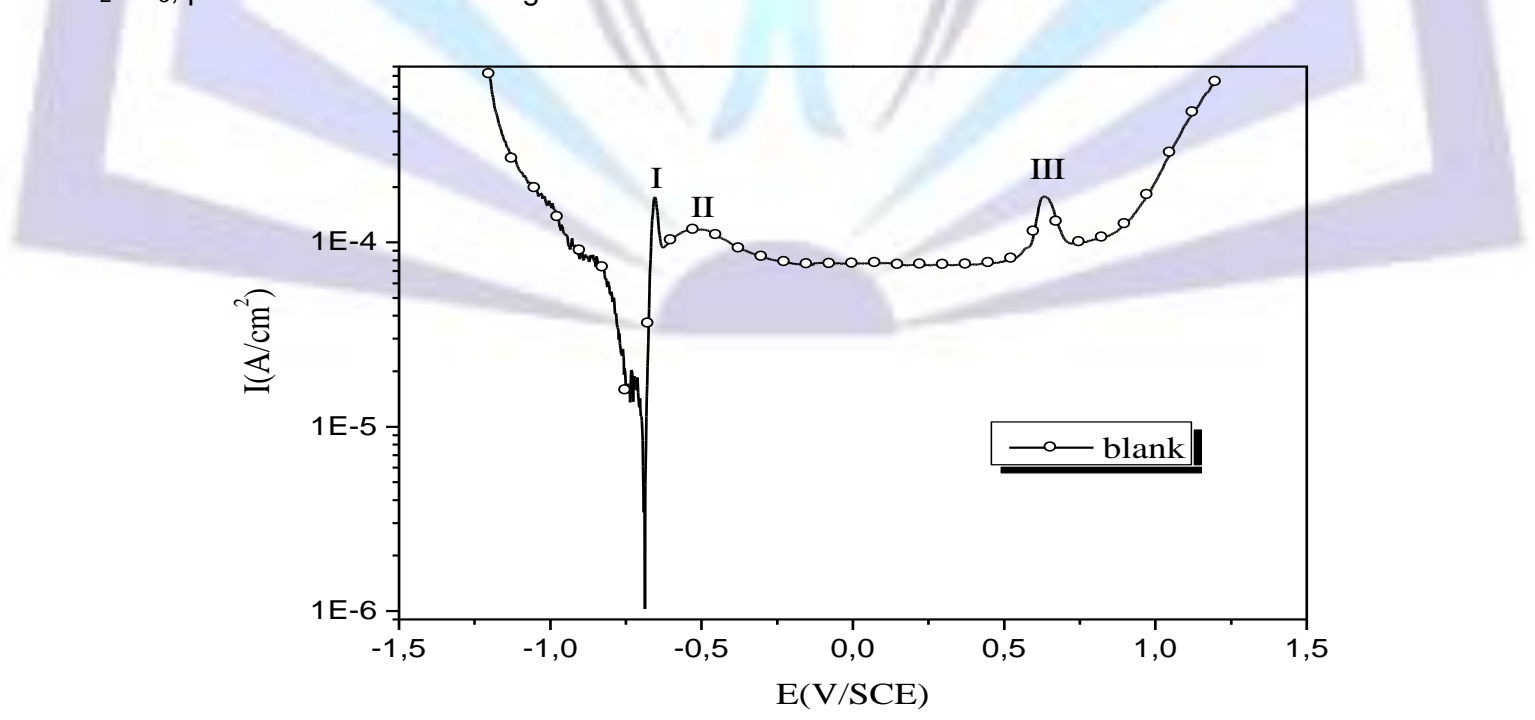

Fig. 1. Potentiodynamic polarisation curves for tin electrode in $0.1 \mathrm{M} \mathrm{Na}_{2} \mathrm{CO}_{3}$ at $298 \mathrm{~K}$ 


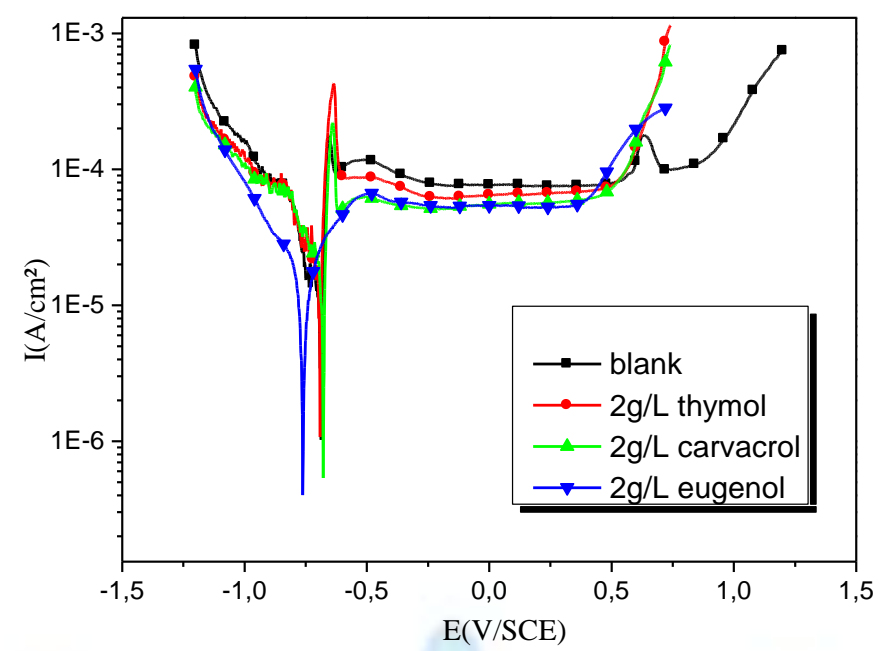

Fig. 2. Polarization curves for tin in $0.1 \mathrm{M} \mathrm{Na}_{2} \mathrm{CO}_{3}$ without and with different inhibitors at $298 \mathrm{~K}$.

the curves of thymol oil and carvacrol oil are almost more confused with that of the free acid solution (blank) reflects the non-functionality of these oils as corrosion inhibitors in these conditions, Except that eugenol oil. The results encourage us to follow the study with this inhibitor.

Eugenol, extract the essential oil of cloves, also known as 4-allyl-2-methoxyphenol (Fig. 3) is an aromatic compound of the family phenylpropenes, a subclass of phenylpropanoid, the empirical formula $\mathrm{C}_{10} \mathrm{H}_{12} \mathrm{O}_{2}$ is used in some products for medical and dental fields because of its analgesic and antiseptic properties [14,25-28]<smiles>C=CCc1ccc(O)c(OC)c1</smiles>

Fig. 3. Chemical structure of Eugenol

\section{3-2. Effet of eugenol concentration}

\section{3-2-1. Potentiodynamic polarization}

The effect of eugenol oil concentration on the anodic and cathodic polarization behavior of tin in $0.1 \mathrm{M} \mathrm{Na}_{2} \mathrm{CO}_{3}$ solution has been studied by polarization measurements and the recorded Tafel plots are shown in Fig.4.

Table 1 shows the electrochemical parameters of tin determined from polarization measurements such as; corrosion potential $\left(E_{c o r}\right)$, corrosion current density $\left(I_{\text {cor }}\right)$, passivation current density $\left(I_{\text {pass }}\right)$ and inhibition efficiency $E_{p}(\%)$ calculed from $I_{\text {cor }}$ values using equation (1). It is clear from Fig. 4 that anodic metal dissolution of tin were inhibited after the addition of eugenol oil in corrosive solution.

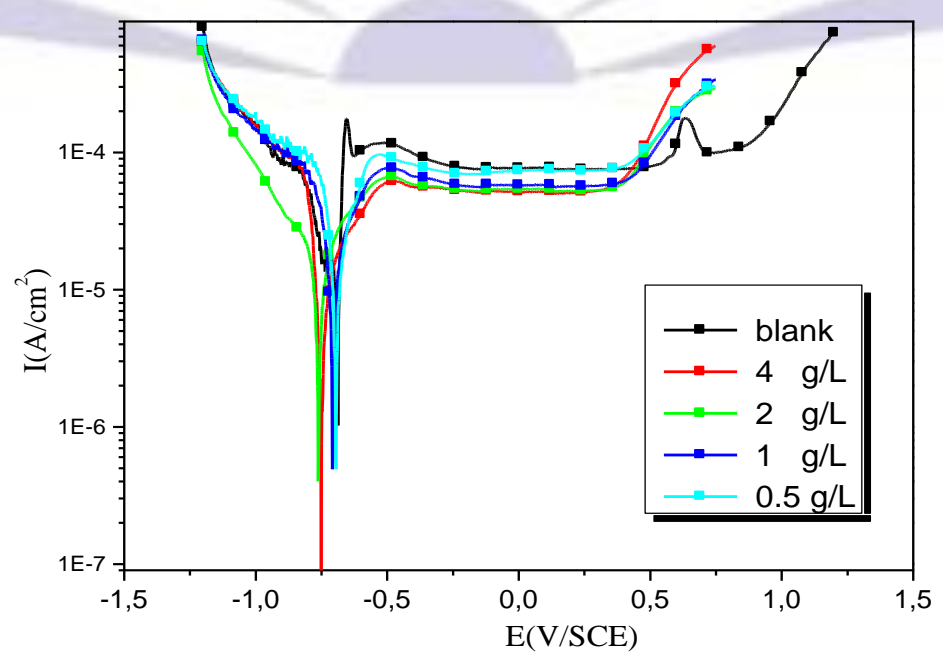

Fig. 4. Polarization curves for tin in $0.1 \mathrm{M} \mathrm{Na}_{2} \mathrm{CO}_{3}$ with and without eugenol oil at $298 \mathrm{~K}$. 
Table 1 : Electrochemical parameters derived from Tafel plots of tin in $0.1 \mathrm{M} \mathrm{Na}_{2} \mathrm{CO}_{3}$ with and without eugenol oil at $298 \mathrm{~K}$.

\begin{tabular}{|c|c|c|c|c|}
\hline Concentration ( $g / L)$ & $I_{\text {cor }}\left(\mathrm{uA} / \mathrm{cm}^{2}\right)$ & $E_{\text {cor }}(\mathrm{mV} / \mathrm{CSE})$ & $I_{\text {pass }}\left(\mu \mathrm{A} / \mathrm{cm}^{2}\right)$ & $E_{p}(\%)$ \\
\hline blank & 30 & -688 & 75 & -- \\
\hline 0.5 & 21 & -693 & 69 & 32 \\
\hline 1.0 & 19 & -703 & 56 & 38 \\
\hline 2.0 & 15 & -757 & 52 & 50 \\
\hline 4.0 & 10 & -754 & 50 & 70 \\
\hline
\end{tabular}

From the figure 4 and table 1 , it is clear that the inhibition efficiency $\left(E_{p} \%\right)$ increases with the increase of eugenol oil concentration reaching a maximum value at a higher concentration $(4 \mathrm{~g} / \mathrm{L})$. This suggests that increase in the inhibitor concentration increases the number of molecules adsorbed over the tin surface, blocking the active sites of solution attack and thereby protecting the metal from corrosion.We note the small variation of Ipass values. The values of corrosion potential nearly remain constant with the addition of eugenol oil. These results indicate that EO acts as a mixed-type inhibitor [29-30].

\section{3-2-2 Electrochemical impedance spectroscopy}

The Nyquist impedance plots for tin in $0.1 \mathrm{M} \mathrm{Na}_{2} \mathrm{CO}_{3}$ in the absence and presence of different concentrations of eugenol oil are shown in Fig. 5. From this Figure, the obtained impedance diagrams almost a semi-circular appearance, indicates that a charge transfer process mainly controls the corrosion of tin,whose size increases with increasing eugenol oil concentration.

The impedance parameters derived from these investigations are listed in Table 2. The values of charge transfer resistance $\left(R_{t}\right)$ increased with the increase of the concentration of Eugenol oil. The decrease in $C_{d l}$ means that the adsorption of this oil takes place on the metal surface[31]. It shows that eugenol is an effective inhibitor for the tin in $0.1 \mathrm{M}$ $\mathrm{Na}_{2} \mathrm{CO}_{3}$ solutions.

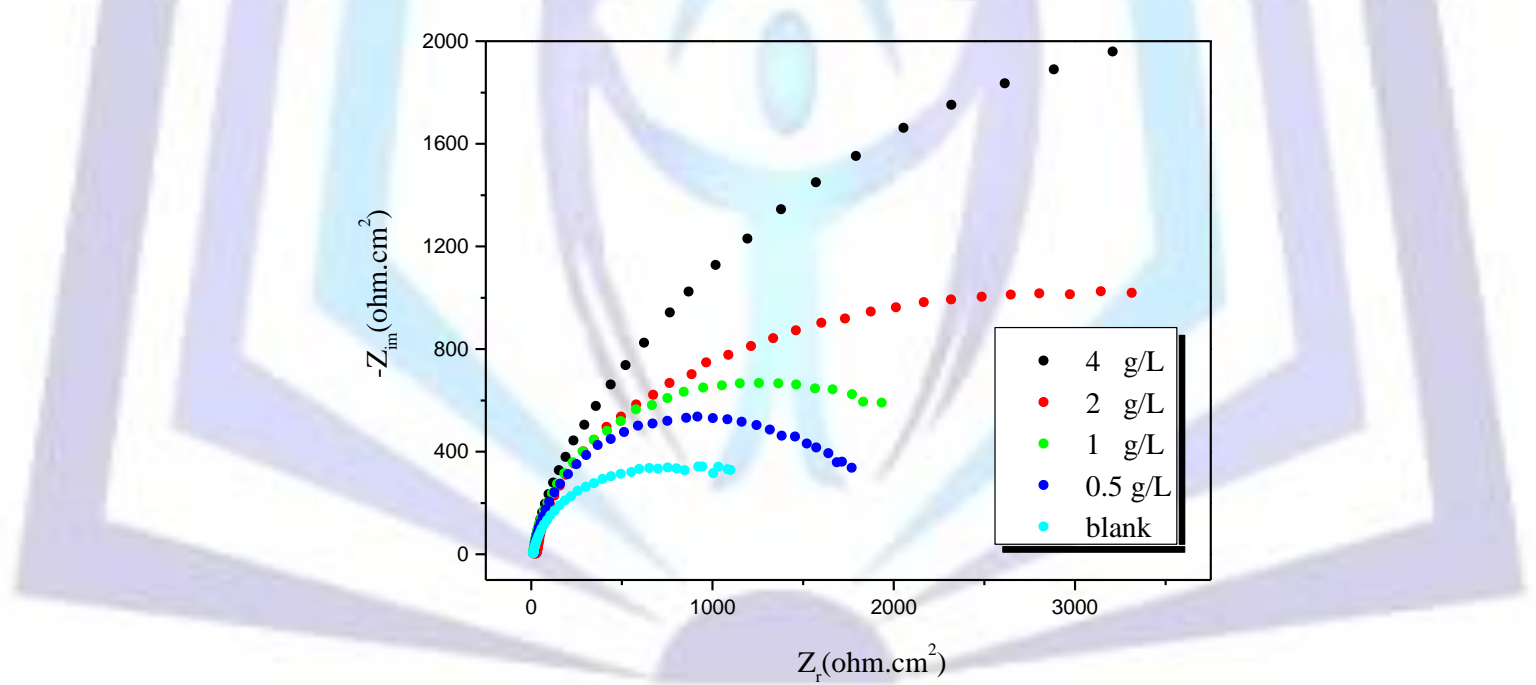

Fig. 5. Nyquist plots for tin in $0.1 \mathrm{M} \mathrm{Na}_{2} \mathrm{CO}_{3}$ at various concentrations of eugenol oil at $298 \mathrm{~K}$.

Table 2. Impedance parameters derived from EIS plots of tin in $0.1 \mathrm{M} \mathrm{Na}_{2} \mathrm{CO}_{3}$ at various concentrations of eugenol oil at $298 \mathrm{~K}$.

\begin{tabular}{|c|c|c|c|c|}
\hline $\begin{array}{c}\mathbf{C} \\
\mathbf{g} / \mathbf{L})\end{array}$ & $\begin{array}{c}\mathbf{R}_{\mathbf{s}} \\
\left(\boldsymbol{\Omega} . \mathrm{cm}^{2}\right)\end{array}$ & $\begin{array}{c}\mathbf{R}_{\mathbf{t}} \\
\left(\mathbf{k} \boldsymbol{\Omega} . \mathrm{cm}^{2}\right)\end{array}$ & $\begin{array}{c}\mathbf{C}_{\mathbf{d l l}} \\
\left(\boldsymbol{\mu} \mathbf{F} / \mathrm{cm}^{2}\right)\end{array}$ & $\begin{array}{c}\mathbf{E}_{\text {ElS }} \\
(\%)\end{array}$ \\
\hline Blank & 12 & 1.195 & 53 & -- \\
\hline 0.5 & 13 & 1.697 & 44 & 30 \\
\hline 1.0 & 10 & 1.955 & 40 & 39 \\
\hline 2.0 & 3 & 2.770 & 33 & 57 \\
\hline 4.0 & 5 & 6.600 & 24 & 82 \\
\hline
\end{tabular}


the inhibition efficiency values obtained from impedance and polarization measurements are in good agreement, confirming that the inhibition action of eugenol for tin corrosion $0.1 \mathrm{M} \mathrm{Na}_{2} \mathrm{CO}_{3}$.

\section{3-3.Effet of temperature}

The temperature is an essential parameter affecting the phenomenon of corrosion. Electrochemical steady state measurements are taken at various temperatures $(278-308 \mathrm{~K})$ in the absence and presence of Eugenol oil $2 \mathrm{~g} / \mathrm{L}$ in $0.1 \mathrm{M}$ $\mathrm{Na}_{2} \mathrm{CO}_{3}$.

\section{3-3-1 polarisation curves}

The effect of temperature on the inhibition efficiency of eugenol oil on the potentiodynamic polarisation curves are shown in Fig. 6 and Fig.7. The respective electrochemical parameters derived from the above plots are given in Table 3.

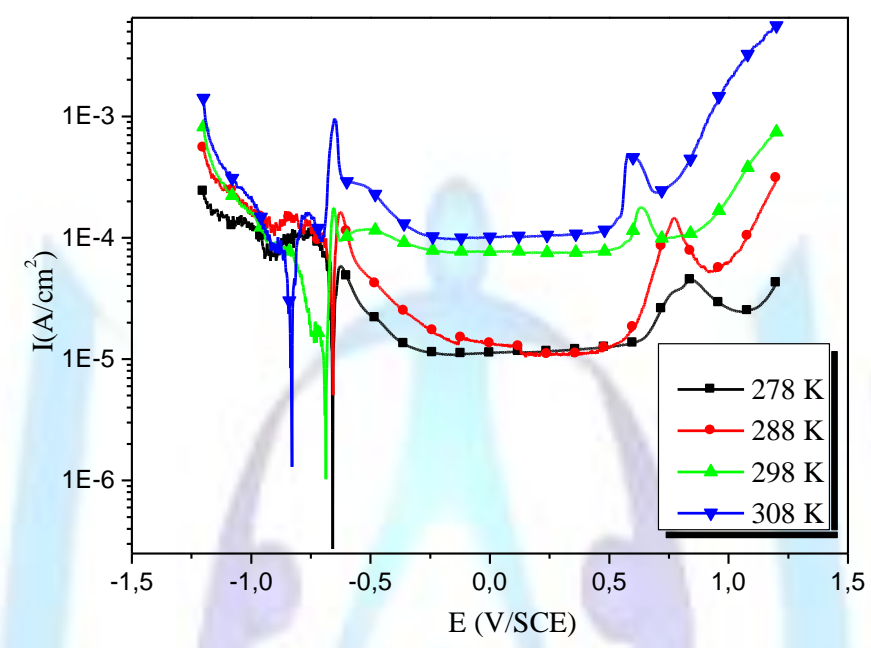

Fig. 6. Tafel plots of tin in $0.1 \mathrm{M} \mathrm{Na}_{2} \mathrm{CO}_{3}$ at different temperatures .

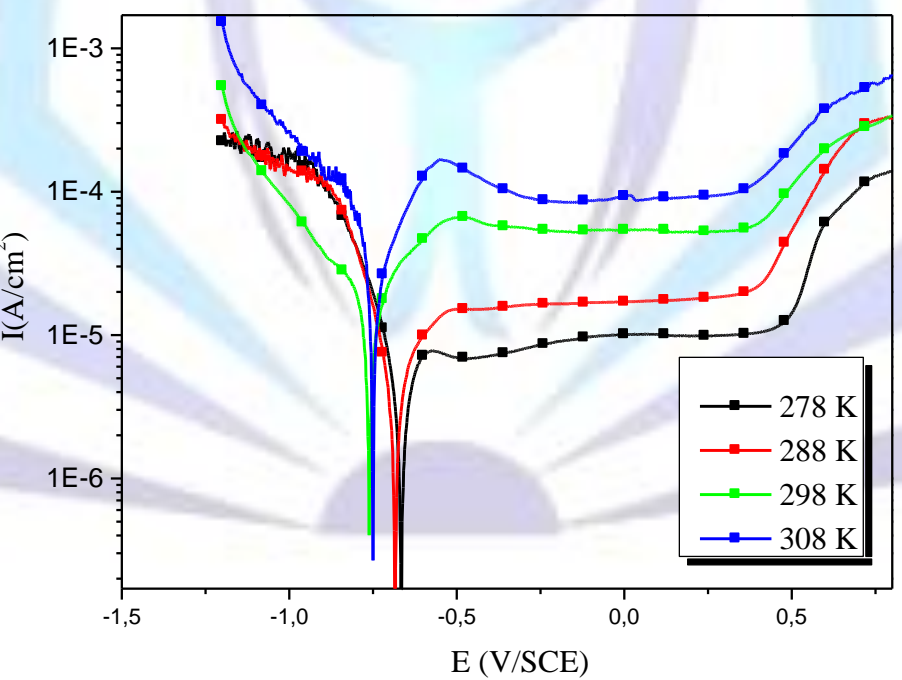

Fig. 7. Tafel plots of tin in $0.1 \mathrm{M} \mathrm{Na}_{2} \mathrm{CO}_{3}$ with eugenol oil $(2 \mathrm{~g} / \mathrm{L})$ at different temperatures. 
Table3 : Electrochemical parameters of tin in $0.1 \mathrm{M} \mathrm{Na}_{2} \mathrm{CO}_{3}$ with or without eugenol oil $(2 \mathrm{~g} / \mathrm{L})$ at different temperatures.

\begin{tabular}{|c|c|c|c|c|c|}
\hline $\begin{array}{c}C \\
(g / L)\end{array}$ & $\begin{array}{c}\text { Temperature } \\
\text { (K) }\end{array}$ & $\begin{array}{c}I_{\text {cor }} \\
\left(\mu \mathrm{A} / \mathrm{cm}^{2}\right)\end{array}$ & $\begin{array}{c}E_{\text {cor }} \\
\text { (mV/SCE) }\end{array}$ & $\begin{array}{c}I_{\text {pass }} \\
\left(\mu \mathrm{A} / \mathrm{cm}^{2}\right)\end{array}$ & $\begin{array}{l}E_{p} \\
(\%)\end{array}$ \\
\hline \multirow{4}{*}{ Blank } & 278 & 18 & -658 & 11 & -- \\
\hline & 288 & 30 & -656 & 51 & -- \\
\hline & 298 & 33 & -688 & 75 & -- \\
\hline & 308 & 48 & -831 & 97 & -- \\
\hline \multirow{4}{*}{2} & 278 & 2 & -662 & 10 & 89 \\
\hline & 288 & 12 & -681 & 42 & 60 \\
\hline & 298 & 15 & -757 & 52 & 55 \\
\hline & 308 & 32 & -744 & 84 & 33 \\
\hline
\end{tabular}

Fig 6 ,fig 7 and table3 indicates that there is a general increase in intensity of corrosion while the temperature increase from 278 to $308 \mathrm{~K}$. The solution become more corrosive with the rise of temperature, for that there was a marked decrease in the inhibition efficiencies. Also we can guess that the molecule of eugenol oil loss its character inhibitor with rise of temperature.

\section{3-3-2 Electrochemical impedance spectroscopy (EIS).}

The effect of temperature on the corrosion behaviour of tin in $0.1 \mathrm{M} \mathrm{Na}_{2} \mathrm{CO}_{3}$ containing inhibitor concentration $(2 \mathrm{~g} / \mathrm{L})$ is studied in the temperature range 278-308 K using impedance diagrams measurements (Fig. 8 and Fig. 9), the corresponding results are summarised in Table 4.

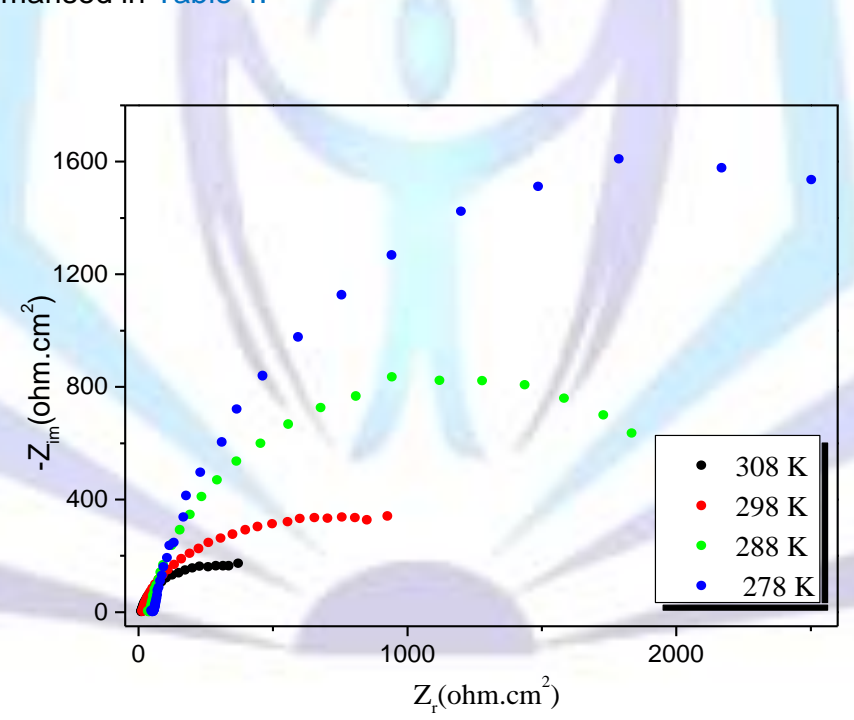

Fig.8. Nyquist plots for tin in $0.1 \mathrm{M} \mathrm{Na}_{2} \mathrm{CO}_{3}$ at differents temperatures. 


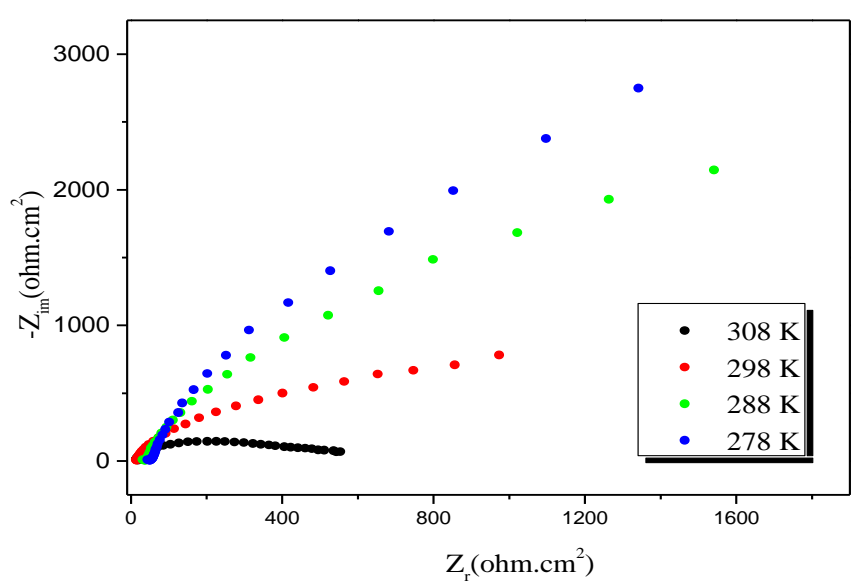

Fig.9. Nyquist plots fortin in $0.1 \mathrm{M} \mathrm{Na}_{2} \mathrm{CO}_{3}$ with eugenol $(2 \mathrm{~g} / \mathrm{L})$ at differents temperatures.

Table4 :Impedance parameters of tin in $0.1 \mathrm{M} \mathrm{Na}_{2} \mathrm{CO}_{3}$ with and without eugenol $(2 \mathrm{~g} / \mathrm{L})$ at differents temperatures.

\begin{tabular}{|c|c|c|c|c|c|}
\hline $\begin{array}{c}C \\
(g / L)\end{array}$ & $\begin{array}{c}\text { Temperature } \\
\text { (K) }\end{array}$ & $\begin{array}{c}\mathbf{R}_{\mathrm{s}} \\
\left(\Omega . \mathrm{cm}^{2}\right)\end{array}$ & $\begin{array}{c}\mathbf{R}_{\mathrm{t}} \\
\left(\mathrm{k} \Omega \cdot \mathrm{cm}^{2}\right)\end{array}$ & $\begin{array}{c}C_{d l} \\
\left(\mu F / \mathrm{cm}^{2}\right)\end{array}$ & $\begin{array}{l}\text { EEIS }_{\text {ES }} \\
(\%)\end{array}$ \\
\hline \multirow{4}{*}{ blank } & 278 & 55 & 3.55 & 20 & -- \\
\hline & 288 & 20 & 1.60 & 29 & -- \\
\hline & 298 & 12 & 1.20 & 42 & -- \\
\hline & 308 & 12 & 0.42 & 24 & -- \\
\hline \multirow{4}{*}{2} & 278 & 39 & 10.47 & 12 & 66 \\
\hline & 288 & 3 & 3.96 & 36 & 60 \\
\hline & 298 & 4 & 2.77 & 32 & 57 \\
\hline & 308 & 8 & 0.55 & 18 & 24 \\
\hline
\end{tabular}

The increase in corrosion rate is more pronounced with the rise of temperature for the uninhibited $0.1 \mathrm{M} \mathrm{Na}_{2} \mathrm{CO}_{3}$ solution The presence of inhibitor leads to decrease of the resistance of transfert. $E_{E I S}(\%)$ depends upon the temperature and decreases with temperature.

\section{3-4.Determination of the activation parameters}

It has been pointed out by number of authors [32-33] that the logarithm of the corrosion rate $(k)$ is a linear function with the reciprocal of the absolute temperature $1 / \mathrm{T}$ (Arrhenius equation):

$$
L n k=-\frac{E_{a}}{R \cdot T}+A
$$

where $E_{a}$ is the apparent effective activation energy, $T$ the absolute temperature, $R$ the universal gas constant, and $A$ is Arrhenius pre-exponential factor. The average activations energy for the dissolution of tin in $0.1 \mathrm{M} \mathrm{Na}_{2} \mathrm{CO}_{3}$ solution between 278 and $308 \mathrm{~K}$ were illustred on Figs.10 and 11. 


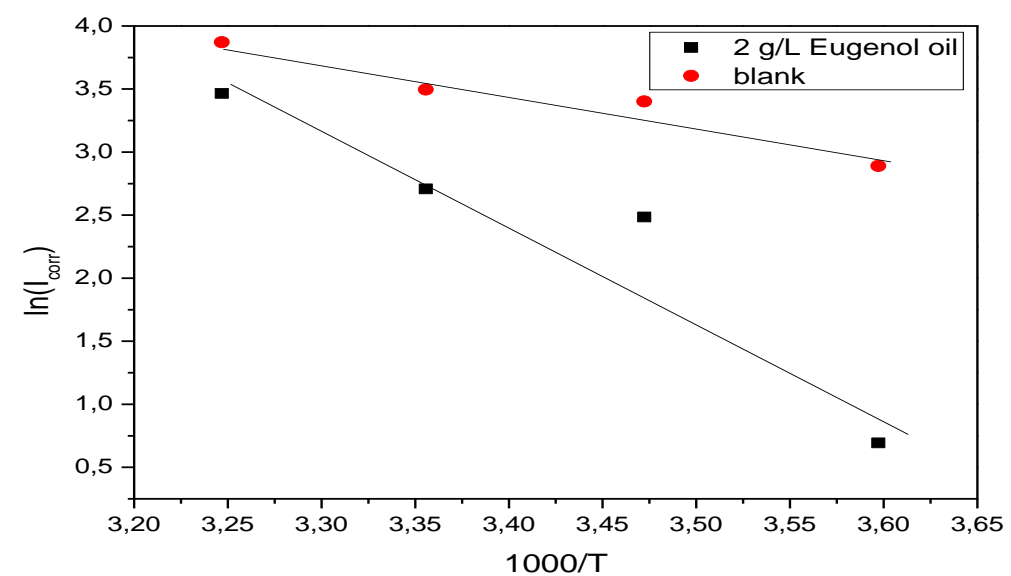

Fig 10. Arrhenius plots of tin in carbonate medium in the absence and presence of EO (Polarisation curves)

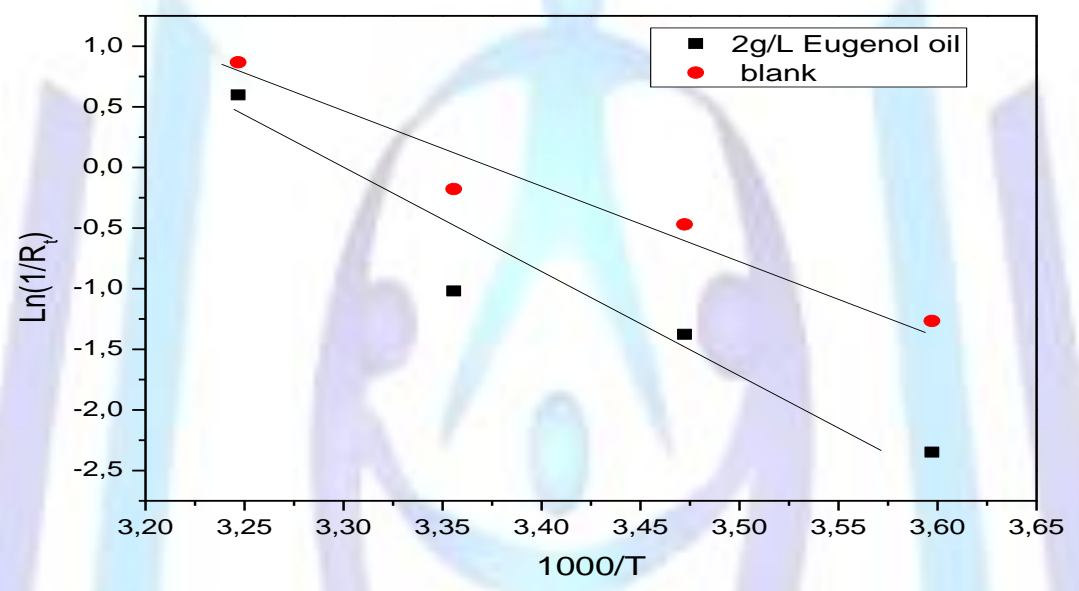

Fig 11. Arrhenius plots of tin in carbonate medium in the absence and presence of EO (EIS)

Table 5 : Activation Energy $E_{a}$ for tin corrosion in the absence and presence of EO.

\begin{tabular}{|c|c|c|}
\hline & Polarization curves & EIS \\
\hline $\mathrm{C}(\mathrm{g} / \mathrm{L})$ & $\mathrm{E}_{\mathrm{a}}\left(\mathrm{kJ} \cdot \mathrm{mol}^{-1}\right)$ & $\mathrm{E}_{\mathrm{a}}\left(\mathrm{kJ} \cdot \mathrm{mol}^{-1}\right)$ \\
\hline blank & 40 & 47 \\
\hline $\mathbf{2}$ & 61 & 65 \\
\hline
\end{tabular}

The values of $E_{a}$ for the corrosion reaction in absence and presence of eugenol oil (Table 5) are calculated by equation (4). The increase in the activation energy $E_{a}$ with the additive inhibitor may be considered to be due to the physical adsorption of the inhibitor[34-35].

\section{4- CONCLUSION}

From the overall experimental results the following conclusions can be deduced:

1. Eugenol oil acts as an mixed-type inhibitor for corrosion of tin in $0.1 \mathrm{M} \mathrm{Na}_{2} \mathrm{CO}_{3}$ solution.

2. The inhibition efficiency increases with increase in the concentration of eugenol oil but decreases with increase in temperature.

3. The inhibition is due to the presence of some the constituents in the eugenol oil which is adsorbed on the surface of the tin metal.

4. The values of $E_{a}$ suggest that the inhibitors were strongly adsorbed on the tin metal surface. 


\section{References:}

[1] E. Ait Addi, L. Bazzi, M. Hilali, E. Zine, R. Salghi, S. El Issami, Can. J. Chem. 81 (2003) 297.

[2] E. Ait Addi, L. Bazzi, M. Elhilali, R. Salghi, B. Hammouti, M. Mihit, App. Surf. Sci. 253 (2006) 555-560.

[3] P.E. Alvarez, S.B. Ribota, M.E. Folquer, C.A. Gervasi, J.R. Vilche, Corros. Sci. 44 (2002) 49.

[4] S.A.M. Refaey, G. Schwitzgebel, App. Surf. Sci. 135 (1998)243-253.

[5] S.A.M. Refaey, Electrochim. Acta 41 (1996) 2545.

[6] J. DE Cuyper « Métallurgie et recyclage de l'étain » Techniques de l'Ingénieur, traité Matériaux métalliques

[7] X. Bill Huang, T. Pete, L. Ying-Sing, Electrochim. Acta 46 (2000) 671-679

[8] H. Ashassi-Sorkhab, D. Seifzadeh, Int. J. Electro- chem. Sci. 1 (2006) 92-98.

[9] A. A. Rahim, E. Rocca, J. Steinmetz, M. J. Kassim, R. Adnan, M. Sani Ibrahim, Corros. Sci. 49 (2007) $402-417$.

[10] E. E. Oguzie, Mater. Chem. Phys. 99(2-3) (2006) 441-446.

[11] M. Pugh, L. M. Warner and D. R. Gabet, Corros. Sci. 7(1967)807-820.

[12] G. Bianchi, Chimicalnd. Milano, 29(1947) 295

[13] M. A. Arenas, A. conde, J. J. de damborenea, Corros. Sci. 44(2002) 511-520.

[14] S. N. Ebrahimi, J. Hadian, M. H. Mirjalili, A. Sonboli, M. Yousefzadi, Food Chem., 110(2008)927-931.

[15] H.H. Hassan, S.S. Abd El Rehim, N.F. Mohamed, Corros. Sci. 44 (2002) 37.

[16] M. S. Abd El Aal, A.H. Osman, Corros., NACE 36 (1981) 591.

[17] M. Drogowska, H. Menard, L. Brossard, J. Appl. Electochem. 21 (1991) 84.

[18] C. A. Gervasi, F. E. Varela, J. R. Vilche, P. E. Alvarez, Electrochim. Acta 42 (1997) 537.

[19] L. Brossard, M. Drogowska, H. Ménard,Trends. corros. Res.,(1993)209.

[20] S.S. Abd El Rehim, F. Taha, M.B. Saleh, S.A. Mohamed, Collect Czech. Chem. Commun. 58 (1993) 2013.

[21] M. Belkhaouda, L. Bazzi, R. Salghi, A. Benlhachemi, B. Hammouti, S. El Issami, M. Hilali, Phys. Chem. News 45 (2009) 137-141.

[22] S. S. Abdel Rehim, S.M. Sayyah, M.M. El Deeb. Mater. Chem. Phys., 80 (2003) 696.

[23] E. E. Foad El-Sherbini. Corros. Sci., 48 (2006) 1093.

[24] M. Pourbaix, Atlas d'équilibres Electrochimiques, Pergamon, Oxford (1966) 475.

[25] R. Schmid, American Journal of Botany, Vol. 59(4)(1972)423-436.

[26] L. A. Shelef, Journal Food Safety, 6(1983)29-44.

[27] C. G. Soto, Burhanuddin, Aquaculture, Vol. 136(1-2)(1995)149-152.

[28] P. Hernández Sánchez, S. López Miranda, C. Lucas Abellán, E. Núñez Delicado, Food and Nutrition Sciences, 3(2012)716-723.

[29]. H. A. Sorkhabi, B. Shaabani, D. Seifzadeh, Appl. Surf. Sci. 239 (2005) 154.

[30]. D. K. Yadav, B. Maiti, M. A. Quraishi, Corros. Sci. 52 (2010) 3586.

[31] A. Bouyanzer, B . Hammouti, L . Majidi, Mat. Letter. 60 (2006) $2840-2843$.

[32] A. A. Khadom, A. S. Yaro, H. K. Abdul Amir, A. S. AlTaie, A. Y. Musa, Am. J. Appl. Sci. 6 (2009) 1403.

[33] F. Bentiss, M. Bouanis, B. Mernari, M. Traisnel, H. Vezin, M. Lagrenee, Appl. Surf. Sci. 253 (2007) 3696.

[34] A. Popova, E. Sokolova, S. Raicheva, M. Christov, Corros. Sci. 45 (2003) 33-58.

[35] K. O. Orubite, N. C. Oforka, Mater. Letter. 58 (2004) 1768 - 1772. 